\title{
Environmentalists fight use of 'untested' pesticide
}

The EPA has been accused of playing politics over Mississippi's fire ant 'emergency'. Clive Cookson reports

ENVIRONMENTALISTS are fighting tenaciously to prevent the use in the southern United States of an untested and allegedly carcinogenic pesticide. They say the Environmental Protection Agency approved the pesticide for political reasons and against the advice of its own scientists.

Twice last year the EPA agreed to requests by the state of Mississippi to use Ferriamicide, a new organochlonine insecticide, as an emergency weapon against fire ants. Each time the Environmental Defense Fund persuaded a federal court to delay the EPA approval. Last month the EPA announced a third time that it would permit Mississippi to apply Ferriamicide to a limited area this spring. But within a fortnight the EDF persuaded the agency to delay the approval againthis time without court action-by drawing its attention to some Canadian research results.

Ferriamicide, developed by Mississippi in a state-owned chemical plant, is a combination of Mirex*, imported from Brazil, with an amine and ferrous chloride to speed up its photodecomposition in the environment. But, according to a recent report by $\mathrm{Dr}$ David Villeneuve, head of the Environmental contaminants section of Health and Welfare Canada (HWC), one of Ferriamicide's main decomposition products, is photo-Mirex, which is even more toxic than Mirex, the active ingredient of Ferriamicide. Pure Mirex was the chief insecticide used against fire ants until the EPA banned it in 1976 after studies indicated that it causes cancer, birth defects, and other toxic effects in mammals.

EDF general counsel William Butler says the Canadian study was widely known before the EPA's most recent approval of Ferriamicide-Dr Villeneuve presented his work at several scientific meetings-but the EPA was apparently not aware of it.

According to the EDF, the agency's whole attitude to Ferriamicide has been influenced by the desire of senior EPA administrators to appease the powerful southern politicians who have been pressing very hard for its approval. Fire ants were accidentally introduced from South America in the 1920s and have spread remorselessly across the South, biting humans and animals and impeding agriculture with their mounds. Controlling the ants has become a big political issue in the nine southern states now infested.

Almost every southern senator and congressman, as well as state and local politicians, joined the campaign to win EPA approval for Ferriamicide. A public relations drive led by Jim Buck Ross, Mississippi's Agriculture Commissioner, persuaded 20,000 people from the state to write to the agency in support of Ferriamicide.

EPA files, which the Environmental Defense Fund obtained during last year's litigation, show that the agency was highly sensitive to this political pressure, though EPA officials insist that the decisions to approve Ferriamicide were not influenced by political considerations. Barbara Blum, EPA deputy administrator wrote on one internal note. "If it's a political decision we want to make the most of it." She was apparently referring to the opportunity to win more favourable treatment for the EPA and for the Administration's pesticides legislation in Congress - the Senate and House committees which oversee the agency and fix its budget have many prominent members from the South.

None of the scientific branches of the EPA pestioides registration division supported their senior administrators' decisions on Ferriamicide. Some, inlife branches, actively opposed them. Nevertheless, Dr Blum ruled that the fire ant "emergency" justified Mississippi's use of its unlicensed and virtually untested pesticide, though she did impose more stringent safeguards than the state proposed. (The eight other infested states lodged similar requests to apply Ferriamicide over a total of 17 million acres, but the EPA has not yet ruled on their cases.)

Dr Blum accepted Mississippi's argument that there is no effective infested areas, although one or two US chemical firms are reported to be developing new ant-killers which may be available soon. The environmentcluding the chemistry and fish and wildalternative treatment for large, heavily alists argue, with the support of some agricultural scientists, that Mirex itself has not halted the spread of fire ants; the area infested has increased from 30 million acres in 1962, when Mirex was first used, to 190 million acres in the late 1970s.

According to William Butler of the EDF, the only result of Mississippi's highly visible war on the ants-involving helicopters and converted B17 aircraft-has been political. Voters can see and hear that the state and federal governments are doing something about the insects which are making their lives miserable. Mr Butler likes to compare the psychology behind the war-and its practical results-with the US attempts to bomb the Vietnamese into submission.

The uncomfortable position of the EPA-under fire from the environmentalists on one side and from the politicians and farmers on the otherbecame more embarrassing when the head of the US Government's other major regulatory agency for toxic chemicals, the Occupational Safety and Health Administration, criticised the latest EPA authorisation of Ferriamicide in Mississippi. What Eula Bingham, Assistant Secretary of Labour responsible for safety and health, objected to was a condition imposed by the EPA that no women of child-bearing age should handle Ferriamicide. OSHA officials are said to fear that this sex bias may be used or quoted as a precedent by chemical firms wishing to exclude women from their work forces.

They also doubt whether the ban on women handling the pesticide makes any sence. Research has indicated that Mirex damages the testes of male rats and may therefore cause fathers to pass on birth defects to their children. Logically, then, only the elderly and sterile should be allowed to use it.

* Chemicallv Mirex is dodecachlorooctahydro - 1,3,4-methano-2H - cyclobuta$(C D)$ pentalene. Photo-Mirex is 8-monohydro-Mirex.

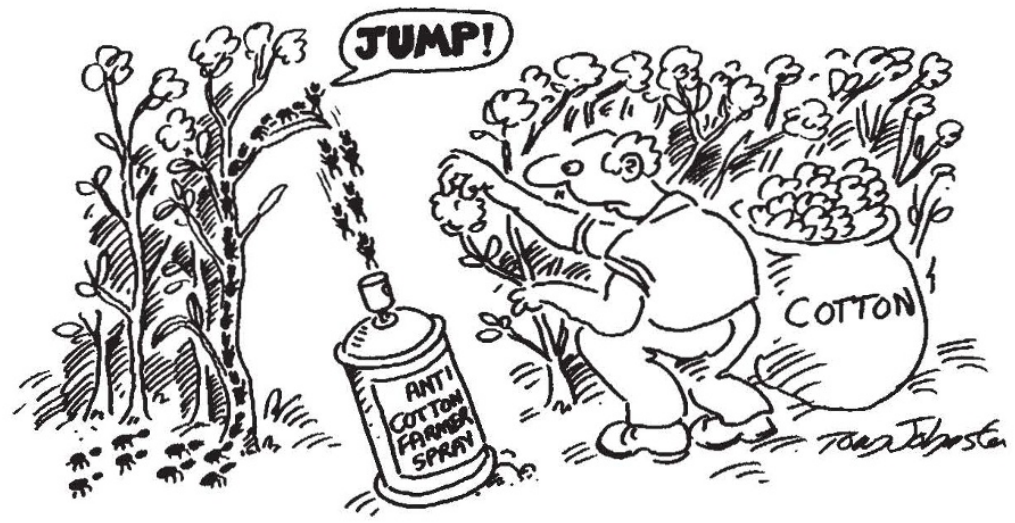

